\title{
The power of school principals' ethical leadership behavior to predict organizational health
}

\author{
Mustafa Özgenel $^{1}$, Tuğba Aksu² \\ ${ }^{1}$ Department of Primary Education, Istanbul Sabahattin Zaim University, Turkey \\ ${ }^{2}$ Nun Schools, Istanbul Sabahattin Zaim University, Turkey
}

\section{Article Info \\ Article history: \\ Received Apr 8, 2020 \\ Revised Aug 12, 2020 \\ Accepted Oct 13, 2020 \\ Keywords: \\ Ethical leadership \\ Ethics \\ Leadership \\ Organizational health}

\begin{abstract}
This study aimed to reveal whether the ethical leadership behaviors of school principals have an impact on organizational health. The relational survey model, one of the quantitative research methods, was preferred as the research method. There were 402 teachers working in public schools in different districts on the Anatolian Side of Istanbul voluntarily participated in the universe of the research in the 2019-2020 academic year. According to the research findings, a positive relationship was found between organizational health and ethical leadership. As the ethical leadership behaviors of school principals increase, the organizational health of the school increases positively. Therefore, it can be said that the ethical behaviors preferred by the principals in the management process are important for the high level of organizational health in schools.
\end{abstract}

This is an open access article under the CC BY-SA license.

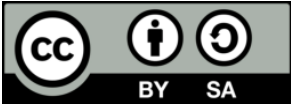

\section{Corresponding Author:}

Mustafa Özgenel,

Department of Primary Education,

İstanbul Sabahattin Zaim University,

34303, Küçükçekmece, İstanbul, Turkey.

Email: mustafa.ozgenel@izu.edu.tr

\section{INTRODUCTION}

The school principal is the leader who will achieve the aims of education, maintain the institution's continuity and provide a positive atmosphere in the school. The school principal gets his status from formal powers. The use of these formal powers together with social and technical powers ensures they are adopted as leaders by other members of the school [1]. At this point, it can be said that the ethical behavior of the school principal as a leader is important in management processes. For example, Şentürk emphasizes the need for the principal to act as an educational leader based on ethical principles in decisions and implementation processes in organizational life [2]. Pehlivan stated the behavior of school administrators is important by emphasizing two points. The first is the school administrator is the most authoritative person of the organization, which aims to undertake educational affairs and acquire correct behavior. The second one stems from the fact that school principals are a "role model" for both institution employees and students [3]. As Pehlivan stated, the behaviors exhibited by the school principal as a role model can be considered to be important both for the school management processes and outcomes, for the performance of teachers and for the architect of our future.

The word root of the concept of ethics comes from Ancient Greek and means about morality. However, the concepts of ethics and morality differ in meaning. While the concept of ethics refers to universality, norms that are universally accepted, the concept of morality is local [4]. The ethical problem, which has an important place in the history of philosophy, has been interpreted by many philosophers under the title of moral philosophy. In short, it can be expressed as a branch of science in search of moral action. By 
questioning human behaviors, the existing behaviors are morally discussed, researched and after the research, they try to define good action [5]. The concept of ethics is a social as well as a universal concept. Therefore, as in all social institutions, we can say it is closely related to educational institutions [6]. The ethical leader derives his leadership power from ethical principles. The ethical leader acts on the compass of ethical principles. It internalizes and incorporates ethical values in decision making and system generation. At the same time, it becomes fair, respectful, tolerant, honest, positive, neutral and gains the trust of its employees [2].

It is seen that globalization and the rapid change it brings today affect our individual, organizational and social values. Therefore, ethical leadership has attracted the attention of researchers in the field of educational administration. When the studies on the ethical leadership approach are examined, it is concluded that the ethical leadership behaviors of school principals are related to many concepts. For instance, there are studies investigating the relationships between ethical leadership behavior and organizational trust and intimidation [7], job satisfaction [3], organizational citizenship [8], organizational commitment [9], organizational trust [10], organizational justice [11], teacher self-efficacy [12], and performance [13]. In the results of the research, it has been determined that there is a positive significant relationship between the ethical leadership behavior and the variables discussed. When the results of the research in the literature are evaluated together, the ethical leadership behaviors exhibited by the school administrators reveal positive results on the school and the teacher in general. In this regard, it can be said that the ethical leader is associated with organizational behavior.

Organizational health can also be considered within the scope of organizational behavior. The concept of organizational health was firstly used by Miles [14]. Miles stated that organizational health has three main dimensions. These; task-centered needs need to maintain life, growth and development needs: 1) The task-centered needs dimension consists of three sub-dimensions. The goal focus: In healthy organizations, members of the organization must know and accept the goal of the system clearly. At the same time, the goal should be stimulating and enhancing productivity. Communication adequacy: In healthy organizations, horizontal and vertical communication between systems is necessary for making correct diagnoses, recognizing intra-organizational tensions and evolving in a positive way, collecting correct and enough data about the source of systemic problems. Optimal power equalization: In health organizations, the effect between subordinate is partially equal. Interpersonal attitude is based on cooperation rather than compulsion. The effect is two-sided. 2) The dimension of the maintenance needs has three sub-dimensions. Resource Utilization: A good harmony is observed between the tendencies of employees in healthy organizations and the role that the system wants. The tension is at the lowest level. Employees are eager to contribute to the organization; professional development is open and job satisfaction is high. Cohesiveness: Members of a healthy organization are proud of their belonging to the institution and are affected by the organization. Morale: In a peaceful and healthy organization, members have positive emotions. Employees have high emotional satisfaction and feelings of happiness. 3) The growth and development needs dimension consist of four sub-dimensions. Innovativeness: A healthy organization should foresee innovations without risking stagnation, set new goals and develop the above standards. Autonomy: individuals do not see the existence of other individuals as a threat and do not accept them as a determinant in their behavior. Adaptation: In managing the difficulties experienced in the process of adaptation to the environment and the organization, it should make its own regulation faster than its environment. Problem-solving adequacy: A healthy organization regularly controls internal and external systems and actively resolves rather than ignoring the problems [15].

Miles examined the organizational health of schools as a model with the concept of "organizational health." Miles has defined a healthy organization as an organization that predicts and takes precautions, turns positive situations into opportunities and adapts quickly to changes, and that can develop continuously [16]. Healthy individuals can grow in healthy environments. Schools are the first environment where individuals are raised and embarked on social life. Organizational health and organizational climate of schools affect their ability to produce healthy products [17]. As an organization, the capacity of the school to cope with the challenges surrounding it and to keep up with changing conditions indicates the level of organizational health. Measuring the organizational health of institutions at regular intervals helps to recognize, eliminate and take precautionary practices within the organization [18]. Hoy, et al. [15] emphasized that the aim is not only to determine the organizational health level of the school but according to the results obtained, an improvement plan should be prepared in the school. The main goal should be to determine what deteriorates the health of the organization. Diagnosis forms the conceptual basis of the solution.

As a result of the literature review on organizational health, a positive and significant relationship was found between organizational health and organizational trust [19], motivation [20], organizational commitment [21], intra-organizational communication [22], organizational culture and organizational climate [19]. As observed from the research results, organizational health represents great importance for 
organizations. Similarly, it is seen that there are studies investigating a significant relationship between the concept of organizational health and various leadership approaches. For example, there are studies to determine the relationship between organizational health and strategic leadership [23], authentic leadership [24] and transformational leadership [25]. But in the literature of education, there are a limited number of studies investigating the effects of school principals' ethical leadership behavior on organizational health. For this reason, in the research, an answer to "Do ethical leadership behaviors of school principals perceived by teachers affect organizational health?" question was sought. The main purpose of the research is to examine the relationship between the principals' ethical leadership behaviors perceived by teachers and organizational health. In addition, answers to the following questions were sought in our research: 1) What is the level of ethical leadership behavior of school principals and organizational health perceived by teachers? 2) Do the ethical leadership behaviors of school principals and organizational health differ significantly according to teachers' (a) gender, (b) seniority, (c) educational background, and (d) educational level? 3) Is there a significant relationship between ethical leadership behaviors of school principals and organizational health? 4) To what extent does school principals' ethical leader behavior predict organizational health?

\section{RESEARCH METHOD}

\subsection{Research design}

This study aimed to reveal whether the ethical leadership behaviors perceived by teachers by school principals have an impact on organizational health. For this purpose, the relational survey model was preferred among the scanning models. Relational survey model is the research examining the relationship between two or more variables [26].

\subsection{Study group}

There were 402 teachers working in public schools in different districts on the Anatolian Side of Istanbul voluntarily participated in the study in the 2019-2020 academic year. Of the teachers participating in the research, 304 are women and 98 are men; 75 of the teachers work in primary school, 172 in secondary school and 155 in high school; 312 of the teachers have bachelor's degrees and 90 of them have postgraduate degrees; 121 of the teachers have 5 years or less, 116 have 6-10 years, 73 have 11-15 years, 53 have 16-20 years, and 39 have 21 years or more seniority.

\subsection{Data collection tools}

In the research, participant Information Form, Ethical Leadership Scale, and Organizational Health Scale were used as data collection tools. Ethical Leadership Scale: In the study, Ethical Leadership Scale (ELS), which is developed by Brown, et al. [27] and adapted to the Turkish by Tuna, et al. [28] was used to determine ethical leadership. The scale consists of 10 items and one dimension. Scale items were created in 5-point Likert style as 1 = strongly disagree, $2=$ disagree, $3=$ neither agree nor disagree, $4=$ agree and $5=$ fully agree. Organizational Health Scale: In the research, Organizational Health Questionnaire (OHQ), which is developed by Lyden and Klingele [29] and adapted to Turkish by Doğan and Bozkurt [30] was used to determine the health of the organization. Organizational Health Scale consists of 20 items. The scale consists of 11 sub-dimensions. Total points are obtained by adding up the points received from all items. Scale items were evaluated as $1=$ Strongly Disagree; 2 = Disagree; $3=$ Undecided; $4=$ Agree; $5=$ Strongly Agree.

\subsection{Data analysis}

Descriptive, skewness, kurtosis and Cronbach Alpha reliability values were calculated before the data analysis. When the results of the data are analyzed in Table 1, it is seen that it shows normal distribution (skewness and kurtosis) and is reliable. Data were analyzed by independent group t-test, ANOVA, correlation and regression analysis.

Table 1. Averages of teachers' ethical leadership perceptions and effects on organizational health, standard deviations, skewness, kurtosis and reliability coefficients

\begin{tabular}{cccccc}
\hline & $\mathrm{N}$ & $\mathrm{M}$ & $\mathrm{SD}$ & Skewness & Kurtosis \\
\hline Ethical Leadership (EL) & 402 & 3.675 & .778 & -.587 & .551 \\
Organizational Health OH & 402 & 3.702 & .663 & -.428 & .770 \\
\hline
\end{tabular}




\section{RESULTS}

The t-test results are given in Table 2 to determine whether school principals' ethical leadership behaviors perceived by teachers and organizational health differ significantly according to the gender of the teachers. When Table 2 is examined, it is seen that teachers' ethical leadership perceptions show a significant difference according to their gender $(\mathrm{t}[400]=2.247 ; \mathrm{p}<.05)$. Ethical leadership perceptions of male teachers $(\mathrm{M}=3.8280)$ are higher than that of female teachers $(\mathrm{M}=3.6258)$. However, teachers' perceptions of organizational health do not differ significantly according to their gender ( $\mathrm{t}[400]=1.431 ; \mathrm{p}>.05)$. The $\mathrm{t}$-test results are given in Table 3 to determine whether the school principals' ethical leadership behaviors perceived by the teachers and organizational health differ significantly according to the educational status of the teachers.

Table 2. Comparison of teachers' perceptions of ethical leadership and organizational health by gender

\begin{tabular}{cccccccc}
\hline Variables & Groups & $\mathrm{N}$ & $\mathrm{M}$ & $\mathrm{SD}$ & $\mathrm{t}$ & $\mathrm{df}$ & $\mathrm{P}$ \\
\hline \multirow{2}{*}{ Ethical Leadership (EL) } & Female & 304 & 3.625 & .784 & \multirow{2}{*}{-2.247} & \multirow{2}{*}{400} & \multirow{2}{*}{.025} \\
& Male & 98 & 3.828 & .742 & & & \\
\multirow{2}{*}{ Organizational Health $(\mathrm{OH})$} & Female & 304 & 3.675 & .678 & -1.431 & 400 & .153 \\
\hline & Male & 98 & 3.786 & .610 & -1.45 \\
\hline
\end{tabular}

Table 3. Comparison of teachers' perceptions of ethical leadership and organizational health by educational

\begin{tabular}{|c|c|c|c|c|c|c|c|}
\hline \multicolumn{8}{|c|}{ status } \\
\hline Variables & Groups & $\mathrm{N}$ & $\mathrm{M}$ & SD & $\mathrm{t}$ & df & $\mathrm{P}$ \\
\hline \multirow{2}{*}{ Ethical Leadership (EL) } & Bachelor's & 312 & 3.721 & .730 & \multirow{2}{*}{2.241} & \multirow{2}{*}{400} & \multirow{2}{*}{.026} \\
\hline & Postgraduate & 90 & 3.513 & .912 & & & \\
\hline \multirow{2}{*}{ Organizational Health $(\mathrm{OH})$} & Bachelor's & 312 & 3.730 & .640 & \multirow{2}{*}{1.579} & \multirow{2}{*}{400} & \multirow{2}{*}{.115} \\
\hline & Postgraduate & 90 & 3.605 & .733 & & & \\
\hline
\end{tabular}

When Table 3 is analyzed, it is seen that teachers' ethical leadership perceptions differ significantly according to their educational status $(\mathrm{t}[400]=2.241 ; \mathrm{p}<.05)$. Ethical leadership perceptions of teachers with bachelor's degrees $(M=3.7216)$ are higher than teachers with a postgraduate degree $(M=$ 3.5139). However, teachers' perceptions of organizational health do not differ significantly according to their educational status $(\mathrm{t}[400]=1.579 ; \mathrm{p}>.05)$. ANOVA analysis was carried out to determine whether the school principals' perceived ethical leadership behaviors and organizational health perceived by teachers were significantly different in terms of seniority. The results of the analysis are given in Table 4 .

Table 4. Comparison of teachers' perceptions of ethical leadership and organizational health according to

\begin{tabular}{|c|c|c|c|c|c|c|c|c|c|c|c|}
\hline \multirow{4}{*}{ EL } & A-5 years and under & 121 & 3.603 & .808 & Btw. G. & 2.96 & 4 & .742 & \multirow{4}{*}{1.227} & \multirow{4}{*}{.299} & \multirow{4}{*}{---} \\
\hline & C-11-15 years & 73 & 3.762 & .725 & Total & 242.9 & 401 & & & & \\
\hline & D-16-20 years & 53 & 3.689 & .857 & & & & & & & \\
\hline & $\mathrm{E}-21+$ & 39 & 3.500 & .868 & & & & & & & \\
\hline \multirow{5}{*}{$\mathrm{OH}$} & B-6-10 years & 116 & 3.712 & .691 & W. G. & 175.8 & 397 & .443 & \multirow{5}{*}{.499} & \multirow{5}{*}{.736} & \multirow{5}{*}{---} \\
\hline & C-11-15 years & 73 & 3.715 & .615 & Total & 176.6 & 401 & & & & \\
\hline & D-16-20 years & 53 & 3.761 & .663 & & & & & & & \\
\hline & $\mathrm{E}-21+$ & 39 & 3.570 & .762 & & & & & & & \\
\hline & Total & 402 & 3.702 & .663 & & & & & & & \\
\hline
\end{tabular}

According to Table 4, teachers' perceptions of school health and ethical leadership do not differ significantly from their seniority. ANOVA analysis was carried out to determine whether school principals' ethical leadership behaviors perceived by teachers and organizational health differ significantly from teachers' school levels. The results of the analysis are given in Table 5. 
Table 5. Comparison of teachers' perceptions of ethical leadership and organizational health according to their school level

\begin{tabular}{|c|c|c|c|c|c|c|c|c|c|c|c|}
\hline & School Level & $N$ & $M$ & $S D$ & $\begin{array}{c}\text { Variance } \\
\text { Source }\end{array}$ & $\begin{array}{c}\text { Sum of } \\
\text { Squares }\end{array}$ & $d f$ & $\begin{array}{c}\text { Mean } \\
\text { Square }\end{array}$ & $\mathrm{F}$ & $\mathrm{p}$ & Sig. \\
\hline \multirow{4}{*}{ EL } & A-Primary & 75 & 3.941 & .607 & Btw. G. & 7.333 & 2 & 3.666 & \multirow{4}{*}{6.20} & \multirow{4}{*}{.002} & \multirow{4}{*}{$\begin{array}{l}\mathrm{A}>\mathrm{B} ; \\
\mathrm{A}>\mathrm{C} ;\end{array}$} \\
\hline & B-Secondary & 172 & 3.660 & .767 & W. G. & 235.626 & 399 & .591 & & & \\
\hline & C-High School & 155 & 3.562 & .835 & Total & 242.959 & 401 & & & & \\
\hline & Total & 402 & 3.675 & .778 & & & & & & & \\
\hline \multirow{4}{*}{$\mathrm{OH}$} & A-Primary & 75 & 3.882 & .609 & Btw. G. & 3.132 & 2 & 1.566 & \multirow{4}{*}{3.60} & \multirow{4}{*}{.028} & \multirow{4}{*}{$\mathrm{A}>\mathrm{C}$} \\
\hline & B-Secondary & 172 & 3.681 & .663 & W. G. & 173.558 & 399 & .435 & & & \\
\hline & C-High School & 155 & 3.639 & .677 & Total & 76.689 & 401 & & & & \\
\hline & Total & 402 & 3.702 & .663 & & & & & & & \\
\hline
\end{tabular}

*Btw: Between Groups, W. G.: Within Groups: **p<.05

According to Table 5, teachers 'perceptions of school health and ethical leadership differ significantly among teachers' levels of duty school ( $\mathrm{p}<.05$ ). According to Table 5, teachers 'perceptions of school health and ethical leadership differ significantly among teachers' levels of duty school ( $p<.05)$. According to the Scheffe Test result to determine which groups differ significantly; The ethical leadership perceptions of teachers working in primary schools $(\mathrm{M}=3.941)$ are higher than the teachers working in secondary school $(\mathrm{M}=3.660)$ and high school $(\mathrm{M}=3.562)$ levels. In addition, the perception of the school health of teachers working in primary schools $(\mathrm{M}=3.882)$ is higher than the teachers working in high school $(\mathrm{M}=3.639)$ levels. In other words, as school level progresses from primary school to secondary school and high school, teachers' perceptions of ethical leadership and organizational health decrease. Correlation analysis conducted to determine whether there is a relationship between the ethical leadership behaviors perceived by the teachers and the health of the organization. The results are shown in Table 6 .

Table 6. Correlation analysis results between teachers' ethical leadership perceptions and organizational health

\begin{tabular}{ccc}
\hline & & Organizational Health \\
\hline \multirow{3}{*}{ Ethical Leadership } & $\mathrm{r}$ & $.792^{* *}$ \\
& $\mathrm{p}$ & .000 \\
& $\mathrm{n}$ & 402 \\
\hline$* *$ Correlation is significant at the 0.01 level
\end{tabular}

When Table 6 is examined, it is seen that there is a high and positive relationship between teachers' ethical leadership perceptions and organizational health $(\mathrm{r}=.792 ; \mathrm{p} .<0.01)$. The results of the regression analysis carried out to determine the level of predicting the ethical leadership behaviors perceived by teachers by the school principals are shown in Table 7.

Table 7. Regression analysis of teachers' ethical leadership perceptions predicting organizational health

\begin{tabular}{|c|c|c|c|c|c|c|c|c|c|c|}
\hline $\begin{array}{l}\text { Independent } \\
\text { Variable }\end{array}$ & $\begin{array}{l}\text { Dependent } \\
\text { Variable }\end{array}$ & B & $\begin{array}{l}\text { Std. } \\
\text { Error. }\end{array}$ & $(\beta)$ & $\mathrm{t}$ & $p$ & $\mathrm{r}$ & $r^{2}$ & $\mathrm{~F}$ & $p$ \\
\hline $\begin{array}{c}\text { Constant } \\
\text { Ethical Leadership }\end{array}$ & $\begin{array}{c}\text { Organizational } \\
\text { Health }\end{array}$ & $\begin{array}{l}1.221 \\
.675 \\
\end{array}$ & $\begin{array}{l}.098 \\
.026 \\
\end{array}$ & .792 & $\begin{array}{l}12.483 \\
25.923\end{array}$ & $\begin{array}{l}.000 \\
.000 \\
\end{array}$ & .792 & .627 & 672.028 & .000 \\
\hline
\end{tabular}

When Table 7 is analyzed, it is seen that there is a high and positive relationship between the ethical leadership behaviors perceived by teachers and organizational health $(r=.792 ; \mathrm{p}<.01)$ and ethical leadership behaviors of school principals predict organizational health significantly $\left(\mathrm{t}[402]=25.923 ; \mathrm{r}^{2}=.627 ; \mathrm{p} .<01\right)$. Ethical leadership behaviors of school principals explain $62.7 \%$ of the total variance in organizational health $(\beta=.792 ; \mathrm{F}=672.02 ; \mathrm{p}<.01)$. As a result, ethical leadership behaviors of school principals affect organizational health positively. One unit increase in ethical leadership behaviors of school principals provides a .792 unit increase in organizational health.

\section{DISCUSSION}

The main purpose of this research is to determine whether the ethical leadership behaviors perceived by teachers of school principals have an impact on organizational health. In this context, it was aimed to 
determine whether teachers 'perceptions of ethical leadership and organizational health differ significantly according to their gender, educational status, seniority, and the level of school they work in and whether school principals' behavior of ethical leadership predicts organizational health. According to the results obtained in the research, the ethical leadership perceptions of teachers show a significant difference according to their gender. Ethical leadership perceptions of male teachers are higher than that of female teachers. Similarly, there are studies in the literature suggesting that male teachers perceive ethical leadership behaviors of school principals higher than female teachers [31-35]. In other words, it can be said that male teachers perceive school principals as more ethical leaders, and female teachers perceive school principals more as executive leaders [36, 37].

Karadas [35] stated that this difference in perception is due to the differences in the expectations of teachers according to gender and that the expectations of female teachers may be higher than that of male teachers. Unlike these results, it is possible to come across studies that reveal that employees' ethical leadership perceptions do not differ significantly according to their gender [38-44]. In our study, while male teachers perceived that school principals adequately demonstrate ethical leadership behaviors; female teachers do not perceive these ethical behaviors of school principals at the same level. According to this result, it can be said that female teachers do not find the ethical leadership behaviors of school principals enough. However, when other data are analyzed, it should be taken into consideration that ethical leadership perception may vary according to the sector studied.

In the research, ethical leadership perceptions of teachers who have a bachelor's degree are higher than those of postgraduate degrees. Similarly, when the researches conducted in educational and profitoriented organizations are examined, there are studies that determine that the perception of ethical leadership decreases as the level of education of individuals increases from high school to postgraduate [33, 36], there is no significant relationship between the perception of education and ethical leadership. It is possible to come across studies [31, 35, 37, 39, 40]. Therefore, it can be concluded that the findings obtained are not consistent, and the findings may vary according to the organizational structure. In addition, it can be thought that teachers with postgraduate education are evaluated with a more critical perspective on ethical leadership behaviors of school principals than bachelors.

According to another finding, teachers' ethical leadership perceptions do not differ significantly according to their seniority. When the literature is analyzed, similar research has been found that does not affect the ethical leadership perception of employees [12, 31, 33, 35, 37, 39, 42, 45]. In addition, Al-Omari, et al. [32] revealed that teachers' ethical leadership perceptions differ significantly according to their seniority. Similarly, Arıkök [40] stated that the employees with seniority less than 1 year have higher ethical leadership perceptions than those who have seniority between 11-15 years. Despite the different findings, based on these results, teachers with different seniority perceive ethical leadership behaviors of school principals alike.

In the study, the ethical leadership perceptions of school principals differ significantly according to the school levels of teachers. The ethical leadership perceptions of teachers working in primary schools are higher than the teachers working in secondary and high school levels. However, Karadaş [35] determined that teachers working in primary and secondary levels are not similar to their ethical leadership perceptions. Similarly, Haban [46], in his study at Anatolian High School, Vocational High School, and Imam Hatip High Schools, stated that teachers' ethical leadership perceptions do not differ according to the type of school they work in. No other research comparing the ethical leadership perceptions of teachers in the field of education at primary, secondary and high school levels has been encountered. For this reason, it can be suggested to include the school level variable in similar studies.

According to the results of the research, teachers' perception of organizational health does not differ significantly according to their gender. Similar studies are found in the literature that concludes that teachers' perception of organizational health does not differ by gender [23, 31, 47-49]. It also reached the conclusion that the perception of the organizational health of the personnel working in sports enterprises in Güllui [50] does not differ significantly according to their gender. However, there are studies that conclude that teachers' perceptions of organizational health differ significantly in favor of women [32, 51]. Kemer [52], organizational health perceptions of hotel employees show a significant difference by gender. Accordingly, male employees have more positive thoughts than female employees. As a result, although we have concluded that the perception of organizational health does not differ by gender when the results of the study are examined, it is observed that the gender variable varies in favor of female and male employees. In this case, it can be said that the gender variable contains contingency for the perception of organizational health.

According to another research finding, teachers' perceptions of organizational health do not differ significantly according to their educational status. There are studies in the literature that find out that the educational status of employees does not differ significantly in their perception of organizational health $[50,53]$. In addition, researches in the education and service sector have also come across research that 
concludes that employees' perceptions of organizational health differ significantly based on their level of education. For example, the perception of the organizational health of teachers with bachelor's degrees was found to be significantly different and higher than that of teachers with educational specialization. Participants with postgraduate degrees are also different and higher than the perceptions of teachers with educational specialist degrees [31, 32, 52]. Akyürek [47] and Köse [23] stated the perception of organizational health of teachers who have pre-graduate and bachelor's degrees graduate higher than teachers who have postgraduate degrees. These results show that with the decrease in the education level of the employees, the perception of the organization is increased. Since the expectations of employees with low education levels from organizational health differ from those of those with higher educational levels, the graduates of graduate education may perceive the organizational health of their schools less.

Teachers' perceptions of organizational health do not differ significantly depending on their seniority. However, Chambers [31] found that teachers' perceptions of organizational health differ significantly from the results of participants who have 6-15 years of experience and 26 or more teaching experience. Similarly, Al-Omari et al. [32] perceive the organizational health of their schools more positively than teachers with less than 5 years of experience, 5-10 years and more than 10 years. Akyürek [47] has revealed that teachers whose seniority is less than 3 years perceive their schools' organizational health more positively than teachers with 7-9 years of seniority. However, Mahmudlu [53] concluded that teachers with 11-20 years of seniority perceive the organizational health of their schools more positively than teachers with 5 years of seniority. Ordu [51] concluded that primary education teachers working for 5 years or less had lower perceptions of organizational health than teachers working 11-15 years, 16-20 years and over 21 years. According to the research conducted by Güllü [50], the perception of organizational health of the personnel working in sports enterprises varies significantly according to their seniority in the institution. Organizational health perceptions of employees of sports enterprises with 5 years of seniority are more positive than the other group with 6 years of seniority.

Kemer [52] found that hotel employees show significant differences in their perceptions of organizational health with respect to their working time in the sector. It is seen that employees with higher seniority than 16-20 years in the sector have more positive views than employees with less seniority than 1-5 and less than 1 year. According to these findings, with the increase in the working hours of the employees in the sector; It can be said that they have become accustomed to the sector, their loyalty and loyalty have increased, their participation has increased due to adaptation to the sector, their communication levels are high and their performance is high. Unlike these findings, Gül [48], on the other hand, found that the perception of the health of hospital staff (doctor, midwife, nurse, medical secretary, and other staff) does not differ according to their professional seniority. As a result, when the related researches are examined, it is understood that the employees do not show consistent results according to their seniority of organizational health or their working time in the organization. Considering the sector differences, workload and levels of wear of the employees, the fact that the seniority status is low or high may affect the perception of the health of the organization positively or negatively.

Organizational health varies significantly according to the school levels where teachers work. Teachers working in primary school perceive their school's organizational health more positively than teachers working in high school. Unlike the research result that emerged in this research, Akyürek [47] found that organizational health did not differ according to school levels. However, even if education is not a sector, there are studies similar to the findings reached in this research. For example, Gül [47] found that the organizational health of hospitals varies according to hospital types. He concluded that the perception of the organizational health of private hospital employees is higher than that of public hospital employees. When the organizational health of the enterprises where Kemer [52] hotel employees work, is examined, it is seen that 5-star accommodation establishments generally have more negative views than 3 and 4-star accommodation establishments. In this case, it can be said that the perception of the organizational health of the accommodation companies increases as the star class decreases. Therefore, as a result of the data obtained from the research, the perception of the organizational health of the employees differs according to the type of institution they work.

According to another finding, there is a high level and positive relationship between the ethical leadership behaviors perceived by teachers and the health of the organization; ethical leadership behaviors of school principals predict organizational health meaningful and significantly. In other words, ethical leadership behaviors of school principals affect organizational health significantly. Similarly, Chambers [31], Davoodi, et al. [54], Al-Omari, et al. [32] and Taneri [55] concluded that ethical leadership behaviors are a factor that significantly affects organizational health. To put it differently, ethical leadership behaviors have a positive effect on organizational health [56]. It provides the institutionalization of the institution by having ethical codes by enabling school principals who exhibit ethical leadership behavior to integrate teachers with their own values. 
Organizational culture is expected in schools where ethics are institutionalized. In educational organizations, ethical leaders manage their school with values, not rules. Managing the school with values is important for school effectiveness. In addition to qualifications for success in school management, it should be determined in ethical criteria. For this reason, school administrators are expected to act according to ethical criteria [57]. While, the ethical values/behaviors of school administrators affect the decision-making process [46], a supportive, sincere and collaborative school climate and the normative commitment of teachers to their schools, it negatively affects teachers' attendance and restrictive school climate. Ethical leadership behaviors of school administrators affect teachers' commitment to school, school climate [58] and organizational opposition [59]. It can be regarded as a situation that school principals who have organizational ethical principles and act according to these ethical principles in leadership practices are expected to positively affect organizational health. In other words, when school principals display consistent and exemplary ethical leadership behaviors, it can be concluded that schools' organizational health may be high.

Based on the results of the research, it can be said that the attitudes and behaviors that school principals will exhibit during the management process can contribute to the health of the organization directly or indirectly, positively or negatively. When the literature is examined, it is tried to be determined whether transformational, interactive, authentic and strategic leadership styles have an impact on organizational health $[23,57,60,61]$. Research has shown that there is a direct and meaningful relationship between the leadership style of administrators and the organizational health levels of schools and that leadership styles affect organizational health. Based on the findings, it can be concluded that the leadership styles exhibited by the managers in their organizations have an impact on organizational health. Based on the findings we obtained in our study, it can be thought that ethical leadership supports organizational health in schools and creates a positive atmosphere between the teacher and principal.

School principals exhibiting ethical leadership behaviors, acting in accordance with ethical codes, communicating effectively, directing the school community to a purpose, supporting teachers' professional development, treating teachers fairly, including stakeholders at school in the management process; It can increase teachers' commitment to the leader and can be a tool to create a positive atmosphere in the school environment. As stated by Cemaloglu [60], organizational health supports internal communication, institutional belonging and effective use of resources. From this point of view, it can be said that organizational health is of great importance in achieving the goals of the school. In addition, it can be stated that school principals should care and evaluate the health of the organization in order to identify the sources of the problems, respond to the needs of the institution faster and foresee the change in an agile way [16]. For this reason, school principals may be advised to aim at achieving a certain standard of organizational health in schools, and to measure and monitor organizational health in schools at regular intervals.

\section{CONCLUSION}

In this study, it was revealed that ethical leadership behaviors of school principals significantly affect school health. When school principals share the goals of the school as an ethical leader with the entire school community, establish an effective communication, develop interpersonal attitude collaboratively, harmonize the trends of the employees with the school's goals, support the professional development of the employees, set new and attractive goals, a healthy school will emerge when it harmonizes with peace and environment, and is willing to solve problems. In summary, when school principals internalize ethical principles and act according to these principles in school management processes and leadership practices, they become an exemplary model for teachers, gain teachers' trust and prepare the ground for a healthy school climate. Based on the results obtained, it may be a new research subject that teachers' ethical leadership perceptions differ according to gender and educational status. In addition, while the level of ethical leadership behavior predicting organizational health is so high, it is an interesting result that teachers' gender and educational status differences do not make sense in terms of organizational health. How does the level of the school where teachers work affect ethical leadership and organizational health? As the answer to the question, the ethical leadership and organizational health perceptions of the teachers at the primary school level showed a significant difference compared to the secondary and high school levels. In this case, the underlying causes of the difference in primary schools can be examined. Ethical leadership behaviors of school principals directly affect teachers' perception of organizational health, and ethical leadership training can be given to school principals within the scope of in-service training.

In conclusion, it should be noted that this study has some limitations. The data for the research was collected from a sample of teachers working in public schools on the Anatolian Side of Istanbul. In addition, data were collected at a specific location and a limited time interval. For this reason, the results obtained from the research cannot be generalized for teachers working in private educational institutions. The 
unidimensionality of the ethical leadership scale, which is preferred as a data collection tool, may have limited the association of sub-dimensions of ethical leadership with organizational health.

\section{REFERENCES}

[1] Z. Bursalığlu, Okul yönetiminde yeni yapı ve davranış, Ankara: Pegem, 2002.

[2] C. Șentürk, "Ethical leadership in educational administration," Bilim ve Akılın Aydınlı̆̆ında Ĕgitim, vol. 142, no. 12, pp. 30-34, 2001.

[3] M. Çetin and K. Özcan, "The effect of school administrators' ethical behaviors on teachers' job satisfaction," $M . \ddot{U}$. Atatürk Ĕ̈itim Fakültesi Ĕ̌itim Bilimleri Dergisi, vol. 20, pp. 21-38, 2004.

[4] Ministry of National Education, "What is ethics?" 2020. [Online]. Available: www.meb.gov.tr

[5] A. Pieper, Introduction to ethics (V. Ataman ve G. Sezer, Çev.). Ankara: Ayrıntı Yayınları, 1999.

[6] A. Mahmutoğlu, "Ethics and morality: Similarities, differences and relationships," Türk Idari Dergisi, vol. 463-464, pp. 225-250, 2009.

[7] N. Cemaloğlu and A. Ç. Kılınç, "The relationship between ethical leadership behaviors of primary school administrators and organizational trust and intimidation perceived by teachers," Eğitim ve Bilim, vol. 37, no. 165, pp. 147, 2012.

[8] E. Tabancalı and Z. K. Çakıroğlu, "The relationship between ethical leadership behaviors of school principals and organizational citizenship behaviors of teachers," Mersin Üniversitesi Ë̆itim Fakültesi Dergisi, vol. 13, no. 1, pp. 392-417, 2017.

[9] H. Şimşek Erdoğan, "According to teachers, the relationship between middle school principals 'ethical leadership characteristics and teachers' organizational commitment," Master Thesis, Maltepe University, İstanbul, 2018.

[10] H. Direk, "The effect of ethical leadership behavior on ethical climate and organizational trust," Unpublished Master Thesis, Maltepe University, İstanbul, 2018

[11] A. Yoldaş, "Examining the effects of school administrators 'ethical leadership behaviors on teachers' perceptions of organizational justice," Unpublished master thesis, Bahçeşehir University, İstanbul, 2018.

[12] B. Tutkun, "The relationship between ethical leadership behaviors of teachers and teacher self-efficacy," Unpublished master thesis, Kahramanmaras Sütçü İmam University, Kahramanmaras, 2017.

[13] F. O. Walumbwa, D. M. Mayer, P. Wang, H. Wang, K. Workman and A. L. Christensen, "Linking ethical leadership to employee performance: The roles of leader-member exchange, self-efficacy, and organizational identification," Organizational Behavior and Human Decision Processes, vol. 115, no. 2, pp. 204-213, 2011.

[14] M. Miles, "Planned change and organizational health: Figure and ground," Organizations and Human Behavior: focus on schools, New York: McGraw-Hill, 1965.

[15] W. K. Hoy, C. J. Tarter and R. B. Kottkamp, Open schools/healthy schools: Measuring organizational climate. Newbury Park, CA: Corwin, 1991.

[16] S. Akbaba Altun, Organization Health, Ankara: Nobel, 2001.

[17] S. Akbaba, "Organizational health of secondary schools: Example of Bolu province," Unpublished Ph. D. dissertation, Ankara University, Ankara, 1997.

[18] K. Ardıç and S. Polatcı, "An integrated view of employee welfare and organizational effectiveness: Organizational health," Iktisadi ve İdari Bilimler Dergisi, vol. 21, no. 1, p. 139, 2007

[19] D. Ayduğ, "Examining the relationship between primary school's organizational health and teachers' organizational trust levels," Unpublished Master Thesis, Anadolu University, Eskişehir, 2014.

[20] P. Ö. Ebcim, "The relationship between motivation of teachers working in public primary schools and organizational health" Master Thesis, Maltepe University, İstanbul, 2012.

[21] E. S. Karagüzel, E.S. "Examining the effects of organizational health on organizational commitment," Unpublished Master Thesis, Sakarya University, Sakarya, 2012.

[22] F. İnal Zorel, "The role of intra-organizational communication in preventing psychological violence (mobbing) as a threat to organizational health," Unpublished Master Thesis, Ege Üniversitesi, İzmir, 2009.

[23] A. Aksulu Köse, "The relationship between the strategic leadership behaviors of private school principals and organizational health," Unpublished Master Thesis, Gazi University, Ankara, 2018.

[24] M. Suiçer, "The effect of authentic leadership behavior on organizational health: an application in hotel businesses," Unpublished Master Thesis, Nevşehir Hacı Bektaş Veli University, Nevșehir, 2016.

[25] T. Vural, "The effect of transformative leadership behaviors on organizational health in hotel businesses: A research in Afyonkarahisar," Unpublished master thesis, Afyon Kocatepe University, Afyonkarahisar, 2013.

[26] Ş. Büyüköztürk, et al., Scientific research methods. Ankara: Pegem, 2012

[27] M. E. Brown, et al., "Ethical leadership: A social learning perspective for construct development and testing," Organizational Behavior and Human Decision Processes, vol. 97, no. 2, pp. 117-134, 2005.

[28] M. Tuna, H. Bircan, and M. Yeşiltaş, "Validity and reliability study of ethical leadership scale: Antalya example," Atatürk Üniversitesi İktisadi ve İdari Bilimler Dergisi, vol. 26, no. 2, pp. 143-155, 2012.

[29] J. A. Lyden and W. E. Klingele, "Supervising organizational health," Supervision, vol. 61, no. 12, pp. 3-6, 2000.

[30] A. Doğan and S. Bozkurt, "A study on the measurement of organizational health status of five-star hotels in Istanbul province with the perception of employees," İşletme Íktisadi Enstitüsü Dergisi-Yönetim Dergisi, vol. 19, no. 60, pp. 61-73, 2008.

[31] J. H. Chambers, "The relationship between secondary school teachers' perceptions of principal ethical leadership and organizational health,” Ph. D. dissertation, University of Tennessee, Knoxville, 2011.

Int. J. Eval. \& Res. Educ. Vol. 9, No. 4, December 2020: 816 - 825 
[32] A. Al-Omari, et al., "Ethical leadership among Omani and Jordanian school principals'and its relation to organizational health as perceived by teachers: A comparative study," International Review of Humanities and Scientific Research, vol. 5, no. 2, pp. 182-195, 2020.

[33] T. Karaköse, "High school teachers' perceptions regarding principals' ethical leadership in Turkey," Asia Pacific Education Review, vol. 8, no. 3, pp. 464-477, 2007.

[34] O. Kaya, "Examining the relationship between ethical leadership behaviors of school administrators and social capital levels of teachers," Unpublished Ph. D. dissertation, Gaziantep University, Gaziantep, 2020.

[35] F. Karadaş, "The relationship between ethical leadership behaviors perceived by teachers and motivation levels of teachers," Unpublished Master Thesis, Akdeniz University, Antalya, 2014.

[36] D. Gosmire, M. Morrison, and J. Van Osdel, "Administrators' and teachers' perceptions of the value and current use of the ELCC standards," National Council of Professors of Educational Administration (NCPEA) Educational Leadership Review (ELR), vol. 10, no. 2, 2009.

[37] Z. D. Alioğlu, "Leader's political skills, leader-member interaction, ethical leadership and relationships between some business results," Ph. D. dissertation, Atatürk University, Erzurum, 2019.

[38] G. Acar, "The relationship of ethical leadership behaviors of school administrators with organizational justice and motivation levels of physical education teachers," Unpublished Ph. D. dissertation, Gazi University, Ankara, 2011.

[39] H. E. Akduru, "The role of ethical leadership and psychological security in the impact of climate of diversity on positive psychological capital: a research,” Unpublished Ph. D. dissertation, İstanbul University, İstanbul, 2019.

[40] M. Arıkök, "Effects of ethical leadership and burnout on anti-production business behaviors: An application in Ankara's manufacturing industry," Unpublished Ph. D. dissertation, Kocaeli University, Kocaeli, 2017.

[41] E. Çengelci, "Ethical leadership behaviors of school administrators," Unpublished Master Thesis, Afyon Kocatepe University, Afyonkarahisar, 2014.

[42] M. Işık, "The relationship between ethical leadership characteristics and organizational commitment of school administrators: Beylikdüzü example," Unpublished Master Thesis, Beykent University, İstanbul, 2009.

[43] M. Turhan, "The effect of ethical leadership behaviors of general and vocational high school administrators on social justice in schools," Unpublished Ph. D. dissertation, Firat University, Elazı $\breve{g}, 2007$.

[44] C. T. Uğurlu, "The effect of primary school teachers' ethical leadership and organizational justice behaviors on the organizational commitment levels of primary school teachers," Unpublished Ph. D. dissertation, İnönü University, Malatya, 2009.

[45] M. Gültekin, "Investigation of elementary school administrators' levels of showing ethical leadership behavior in terms of various variables," Unpublished Master Thesis, Selçuk University, Konya, 2008.

[46] M. M. Haban, "A mixed method study on ethical leadership behaviors of secondary school institution administrators," Unpublished Ph. D. dissertation, Gaziantep University, Gaziantep, 2018.

[47] M. İ. Akyürek, "Social capital and organizational health in schools," Unpublished Ph. D. dissertation, Gazi University, Ankara, 2019.

[48] İ. Gül, "The effect of organizational commitment and openness to organizational change on organizational health in health institutions: A research in Afyonkarahisar city center hospitals," Unpublished Ph. D. dissertation, Süleyman Demirel University, Isparta, 2018.

[49] Ç. Yıldız, "Relationship between school administrators' crisis management attitudes and perceived organizational health: The case of Üsküdar District," Unpublished master thesis, Yeditepe University, İstanbul, 2014.

[50] S. Güllü, "The mediating role of organizational health in the effect of leader-member interaction on work quality of life and anti-productivity business behavior: Example of sports firms," Unpublished Ph. D. dissertation, İstanbul University, İstanbul, 2018.

[51] A. Ordu, "Relationships between organizational structure and organizational health in primary schools," Unpublished Ph. D. dissertation, Pamukkale University, Denizli, 2011.

[52] E. Kemer, "The role of organizational identification in the impact of organizational justice on organizational health: A research in hospitality businesses in Nevşehir province," Unpublished Ph. D. dissertation, Hacı Bektaş Veli University, Nevşehir, 2017.

[53] S. Mahmudlu, "The effect of employees' perceptions of organizational health on innovative work behavior: a research on teachers," Unpublished Master Thesis, Ondokuz Mayıs University, Samsun, 2019.

[54] M. O. Davoodi, A. M. Valeie and M. A. Melki, "Analyze the relationships between ethical leadership and organizational health,” Human Resources Studies Quarterly, vol. 3, no. 9, pp. 61-78, 2013.

[55] A. Taneri, "The relationship between ethical leadership and organizational health in primary education institutions: The Case of Aksaray Province,” Unpublished Master Thesis, Gazi Üniversitesi, Eğitim Bilimleri Enstitüsü, 2011.

[56] Y. M. Zhang and X. H. Zhang, "Decision Model of diversification choice in agricultural enterprises: based on the case study of longping high-tech[J]," Journal of Management Case Studies, vol. 10, no. 5, pp. 523-535, 2017.

[57] V. Çelik, Educational leadership, Ankara: Pegem, 2000.

[58] M. Özgenel and D. Yayık, "The relationship between school leaders' ethical leadership characteristics and school climate and teachers' commitments to school," $6^{\text {th }}$ International Symposium on Academic Studies in Educational and Social Sciences, pp. 45-46, 2019.

[59] M. Özgenel, et al., "The relationship between school administrators' ethical leadership competencies and organizational opposition," 3rd International Congress of Eurasian Social Sciences, pp. 317, 2019.

[60] N. Cemaloğlu, "The effect of leadership styles of school administrators on organizational health," Sosyal Araştırmalar Dergisi, vol. 11, no. 2, pp. 165-194, 2007.

[61] C. Y1ldırım, "The effect of school principals' leadership styles on organizational health," Unpublished master thesis, Gazi University, Ankara, 2006.

The power of school principals' ethical leadership behavior to predict organizational ... (Mustafa Özgenel) 